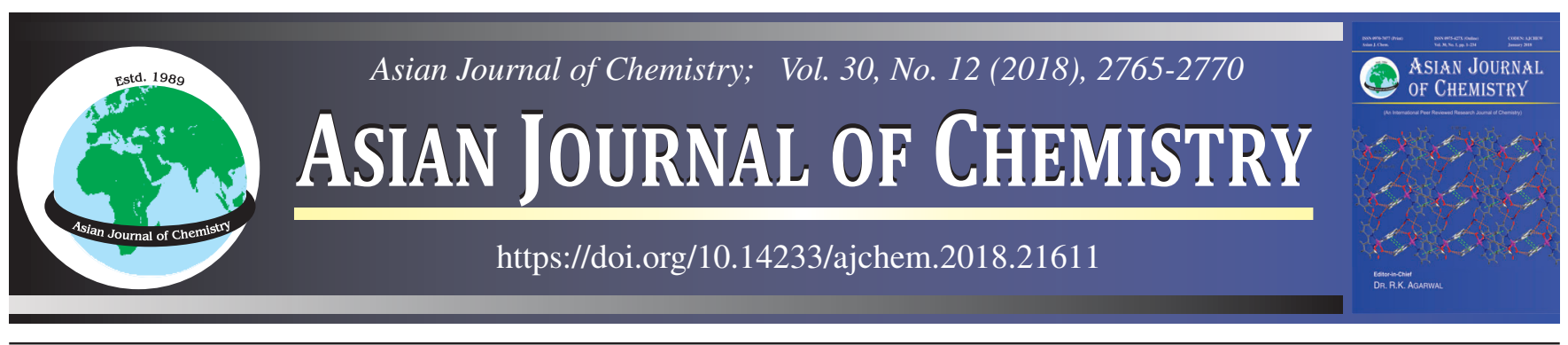

\title{
Removal of Congo Red Dye from Aqueous Solution by Using Limonia acidissima Shell as Adsorbent
}

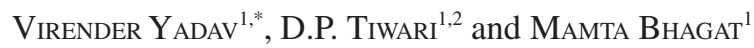

${ }^{1}$ Department of Chemical Engineering, Deenbandhu Chhotu Ram University of Science and Technology, Murthal-131 039, India

${ }^{2}$ Rajiv Gandhi Government Engineering College, Nagrota Bagwan Taluka-176 047, India

*Corresponding author: E-mail: virenderydv@gmail.com

Received: 25 July 2018;

Accepted: 29 September 2018;

Published online: 31 October 2018;

AJC-19145

This research paper highlights the removal of a congo red from aqueous medium by using Limonia acidissima shell. Various factors such
as initial dye concentration, dosage of adsorbent, time contact, effects of temperature and $\mathrm{pH}$ were studied. The characterizations of
adsorbent were done by XRD and FTIR analysis. The equilibrium data analyzed using Freundlich, Langmuir, Temkin and Dubinin
Radushkavich isotherm models. Out of four adsorption isotherm, the $\mathrm{R}^{2}$ value of Langmuir isotherm model was the highest. The maximum
monolayer exposure from Langmuir isotherm model was determined to be $84.48 \mathrm{mg} / \mathrm{g}$, the separation factor $\left(\mathrm{R}_{\mathrm{L}}\right)$ indicating favorable
sorption is 0.76 . The kinetic results inveterate that pseudo-first-order kinetic model explained the removal of Congo red dye by Limonia
acidissima shells in a better way. The rate constant of $2.8 \mathrm{mg} / \mathrm{g}$ min $^{-0.5}$ was shown by intra-particle diffusion model. Thermodynamic
parameters like Gibb's free energy $\left(\Delta \mathrm{G}^{\circ}\right)$, enthalpy change $\left(\Delta \mathrm{H}^{\circ}\right)$ and entropy change $\left(\Delta \mathrm{S}^{\circ}\right)$ illustrated that Congo red dye adsorption onto
Limonia acidissima shells was realistic, spontaneous and endothermic.
Keywords: Congo red, Limonia acidissima shell, Isotherms, Adsorption capacity, Kinetics.

\section{INTRODUCTION}

In the era of industrialization, large quantities of various dyes can be used in many industries, like paper and pulp manufacturing, textiles, printing, food products, leather treatment, etc. [1]. The effluent contains various colourful materials from industries, which further mixed with the surface and groundwater system. It causes a problem to human health such as kideny, liver, brain, and central nervous system due to toxic and carcinogenic dyes [2]. Therefore, it is required to eliminate dye contamination. Due to complex aromatic structures, it can't easily degrade [3]. Therefore, it is necessary to design an appropriate treatment method.

Recently, various methods have been developed which includes biological treatment, reverse osmosis, coagulation, flocculation, chemical oxidation, photodegradation [4] and adsorption [5] for the wastewater treatment containing colour impurities. Among this adsorption is one of best technique due to its effortlessness operation and lower cost compared to other processes. Recently, great attention has been focused on use of agricultural waste for elimination of dyes from wastewater. Several reports on adsorbents includes sawdust [6], hardwood, bagasse [7] and corn cobs [8]. The wood apple shell (Limonia acidissima shell) is an indigenous and ordinary fruit cultured in India. It is used in different culinary preparations, and a large amount of outer shell is discarded as waste. The wood apple shell (Limonia acidissima shell) carries lignocellulosic material [9]. This study aims to eliminate of Congo red dye from the aqueous solution by using Limonia acidissima shells with number of parameters like $\mathrm{pH}$, time, initial dye concentration, time and temperature influence on adsorption behaviour, adsorption isotherm, adsorption kinetics and thermodynamics properties.

\section{EXPERIMENTAL}

The Congo red dye purchased from Lab Chemie (CAS no. 573-58-0). $\mathrm{NaOH}$ and $\mathrm{HCl}$ were bought from Merck, India. Wood apple shell (Limonia acidissima) derived from an economically available and ecological vegetable source.

This is an open access journal, and articles are distributed under the terms of the Creative Commons Attribution-NonCommercial 4.0 International (CC BY-NC 4.0) License, which allows others to copy and redistribute the material in any medium or format, remix, transform, and build upon the material, as long as appropriate credit is given and the new creations are licensed under the identical terms. 
The physio-chemical analysis of sample was done by Fourier transforms infrared spectroscopy (Thermo Scientific Nicole) and X-Ray diffractometer (Rigaku Miniflex). The concentration of dye of solution was determined by UV-visible spectrophotometer (Rigol-3000).

Preparation of adsorbent (Limonia acidissima): The Limonia acidissima shells were collected from the region of Karnal and Sonipat (India) and washed thoroughly with double distilled water (2 times) to remove dust particles.The clean Limonia acidissima shells were dried in sunlight for 2 days and remaining moisture removed by over-night heating in oven at $80^{\circ} \mathrm{C}$. The dried Limonia acidissima shells were grinded and sieved by using different sizes (150 and 300-micron) by sieve shaker. The $300 \mu \mathrm{m}$ sized particles of Limonia acidissima shells were collected and used for further experiments.

Adsorption: The experiments were investigated batchwise to identify the effect of operation parameters likes $\mathrm{pH}$ (2 to 12), time contact (20-140 $\mathrm{min}$ ), adsorbate concentration (50, 60, $70,80,90$ and $100 \mathrm{mg} / \mathrm{L})$, adsorbent dose $(0.5-50 \mathrm{mg})$ and temperatures (303, 313, 323 and $333 \mathrm{~K})$ during the study. All the experiments were performed at laboratory temperature (30 $\pm 5^{\circ} \mathrm{C}$ ), except when effect of temperature was examined. All beakers were shaked for $120 \mathrm{~min}$ with a speed of $100 \mathrm{rpm}$ by using an orbital shaker. The absorbance of supernatant (dye remained in solution after the adsorption) was determined by UV spectrophotometry (Rigol-3000) at $497 \mathrm{~nm}$. All experiments were carried out thrice. The amount of retained dye $\left(\mathrm{q}_{\mathrm{e}}\right)$ at equilibrium was estimated by following equation:

$$
\mathrm{q}_{\mathrm{e}}=\left(\mathrm{C}_{\mathrm{o}}-\mathrm{C}_{\mathrm{e}}\right) \frac{\mathrm{V}}{\mathrm{m}}
$$

where $\mathrm{C}_{\mathrm{o}}$ and $\mathrm{C}_{\mathrm{e}}(\mathrm{mg} / \mathrm{L})$ are initial and equilibrium concentrations of Congo red dye, $\mathrm{V}(\mathrm{L})$ is the volume of solution, $\mathrm{m}$ (g) is the weight of Limonia acidissima shells.

Kinetics and Adsorption parameter: The adsorption of diffusion through a boundary, the pseudo first-order rate model and pseudo second-order rate model were investigated. The pseudo first-order rate model can be expressed as shown in eqn. $2[10,11]$.

$$
\ln \left(\mathrm{q}_{\mathrm{e}}-\mathrm{q}_{\mathrm{t}}\right)=\ln \mathrm{q}_{\mathrm{e}}-\mathrm{K}_{\mathrm{l}} \mathrm{t}
$$

where $\mathrm{q}_{\mathrm{e}}\left(\mathrm{mg} \mathrm{g}^{-1}\right)$ and $\mathrm{q}_{\mathrm{t}}(\mathrm{min})$ are the adsorbed amounts of Limonia acidissima shells at equilibrium and at time ' $t$ ', respectively; $\mathrm{k}_{1}(\mathrm{~min})$ is the adsorption rate constant. The graph plot between $\log \left(\mathrm{q}_{\mathrm{e}}-\mathrm{q}_{\mathrm{t}}\right)$ against $\mathrm{t}$, gives the value of $\mathrm{K}_{1}$ and $\mathrm{q}_{\mathrm{e}}$ from the slope and the intercept of graph. The linearized pseudo second-order rate form [12] (eqn. 3) and intra-particle diffusion model (eqn. 4) were tested.

$$
\begin{gathered}
\frac{\mathrm{t}}{\mathrm{q}_{\mathrm{t}}}=\left(\frac{1}{\mathrm{~K}_{2} \mathrm{q}_{\mathrm{e}}^{2}}+\frac{1}{\mathrm{q}_{\mathrm{e}}} \mathrm{t}\right) \\
\mathrm{q}_{\mathrm{t}}=\mathrm{K}_{\mathrm{id}} \mathrm{t}^{0.5}+\mathrm{C}
\end{gathered}
$$

where $\mathrm{K}_{2}\left(\mathrm{~g} \mathrm{mg}^{-1} \mathrm{~min}^{-1}\right)$ is the adsorption rate constant for pseudo second-order rate model and $\mathrm{q}_{\mathrm{e}}(\mathrm{mg} / \mathrm{g})$ can be calculated from the slope and intercept of graph between $t / q_{t}$ and $t$. And $K_{\text {id }}$ $\left(\mathrm{mg} \mathrm{g}^{-1} \mathrm{~min}^{-0.5}\right)$ is the intra-particle diffusion rate constant and $\mathrm{C}$ is the intercept.

Adsorption isotherm: To uptake adsorption isotherm, including Freundlich, Langmuir,Temkin and Dubinin-Radush- kevich (DR) isotherm models were determined to explain Congo red dye-Limonia acidissima shells interaction. The Langmuir isotherm forms can be written according to the eqn. 5:

$$
\frac{\mathrm{C}_{\mathrm{e}}}{\mathrm{q}_{\mathrm{e}}}=\left(\frac{1}{\mathrm{~K}_{\mathrm{L}} \mathrm{q}_{\mathrm{m}}}+\frac{\mathrm{C}_{\mathrm{e}}}{\mathrm{q}_{\mathrm{m}}}\right)
$$

The graph plot $\left(\mathrm{C}_{\mathrm{e}} / \mathrm{q}_{\mathrm{e}}\right.$ versus $\left.\mathrm{C}_{\mathrm{e}}\right)$ gives higher absorption capacity $\mathrm{q}_{\mathrm{m}}(\mathrm{mg} / \mathrm{g})$ and the Langmuir adsorption constant $\mathrm{K}_{\mathrm{L}}$ (L/mg). The study of feasibility of adsorption by using separation factor $\left(R_{L}\right)$ is shown in eqn. 6 :

$$
\mathrm{R}_{\mathrm{L}}=\frac{1}{\left(1+\mathrm{K}_{\mathrm{L}} \mathrm{C}_{\mathrm{o}}\right)}
$$

where $\mathrm{K}_{\mathrm{L}}(\mathrm{L} / \mathrm{mg})$ and $\mathrm{C}_{\mathrm{o}}(\mathrm{mg} / \mathrm{L})$ are the Langmuir isotherm constant and initial concentration of Congo red dye, respectively. The $\mathrm{R}_{\mathrm{L}}$ value between 0 and 1 , gives the favorability of adsorption process [13]. The Freundlich model was determined the interaction relationship between Congo red and Limonia acidissima shells particles by eqn. 7 :

$$
\log \mathrm{q}_{\mathrm{e}}=\log \mathrm{K}_{\mathrm{f}}+\frac{1}{\mathrm{n}} \log \mathrm{C}_{\mathrm{e}}
$$

where $\mathrm{q}_{\mathrm{e}}(\mathrm{mg} / \mathrm{g})$ and $\mathrm{C}_{\mathrm{e}}(\mathrm{mg} / \mathrm{L})$ are the quantity of Congo red dye retained at equilibrium and concentration at equilibrium of dye solution, respectively. The degree of sorption $\mathrm{K}_{\mathrm{f}}$ and intensity of adsorption $1 / \mathrm{n}$ were obtained from the gradient and intercept $\log \mathrm{q}_{\mathrm{e}}$ versus $\log \mathrm{C}_{\mathrm{e}}$ [14]. Furthermore, if $\mathrm{n}>1$, this represents a favourable adsorption isotherm [13].The Temkin isotherm model [15] was determined the relationship between adsorbent and adsorbate interaction as shown in eqn. 8:

$$
\mathrm{q}_{\mathrm{e}}=\mathrm{B} \ln \mathrm{AT}+\mathrm{B} \ln \mathrm{C}_{\mathrm{e}}
$$

The equilibrium binding energy $A_{T}(L / m o l)$ and heat of adsorption $B$ determine from the gradient and intercept of graph between $\mathrm{q}_{\mathrm{e}}$ against $\ln \mathrm{C}_{\mathrm{e}}$. The linear Dubinin-Radushkevitch adsorption isotherm [16] eqn. 9 may be written as:

$$
\ln \mathrm{q}_{\mathrm{e}}=\ln \mathrm{q}_{\mathrm{m}}-\left(\beta \varepsilon^{2}\right)
$$

where $\beta\left(\mathrm{mol}^{2} / \mathrm{kJ}^{2}\right)$ and $\mathrm{q}_{\mathrm{m}}(\mathrm{mg} / \mathrm{g})$ are the adsorption energy and degree of adsorbent: $\varepsilon$ is the Polanyi potential was estimated by eqn. 10 :

$$
\varepsilon=\mathrm{RT} \ln \left(1+\frac{1}{\mathrm{C}_{\mathrm{e}}}\right)
$$

where $\mathrm{T}(\mathrm{K})$ and $\mathrm{R}(\mathrm{J} / \mathrm{mol} \mathrm{K})$ are the temperature and gas constant. A linear graph plot between $\ln \mathrm{q}_{\mathrm{e}}$ versus $\varepsilon^{2}$, gives $\beta$ and $\mathrm{q}_{\mathrm{m}}$ from the slope and the intercept, respectively.

Adsorption thermodynamic parameters: Adsorption thermodynamic properties likes Gibb's free energy change $\left(\Delta \mathrm{G}^{\circ}\right)$, enthalpy change $\left(\Delta \mathrm{H}^{\circ}\right)$ and entropy change $\left(\Delta \mathrm{S}^{\circ}\right)$ were calculated using the subsequent equations:

$$
\mathrm{K}_{\mathrm{c}}=\frac{\mathrm{C}_{\mathrm{e}}}{\mathrm{C}_{\mathrm{o}}-\mathrm{C}_{\mathrm{e}}}
$$

where $\mathrm{K}_{\mathrm{c}}$ is the constant, $\mathrm{C}_{\mathrm{o}}$ and $\mathrm{C}_{\mathrm{e}}(\mathrm{mg} / \mathrm{L})$ are the initial ion concentration and the amount of Congo red dye adsorbed at equilibrium, respectively.

$$
\Delta \mathrm{G}^{\circ}=-\mathrm{RT} \ln \mathrm{K}_{\mathrm{c}}
$$




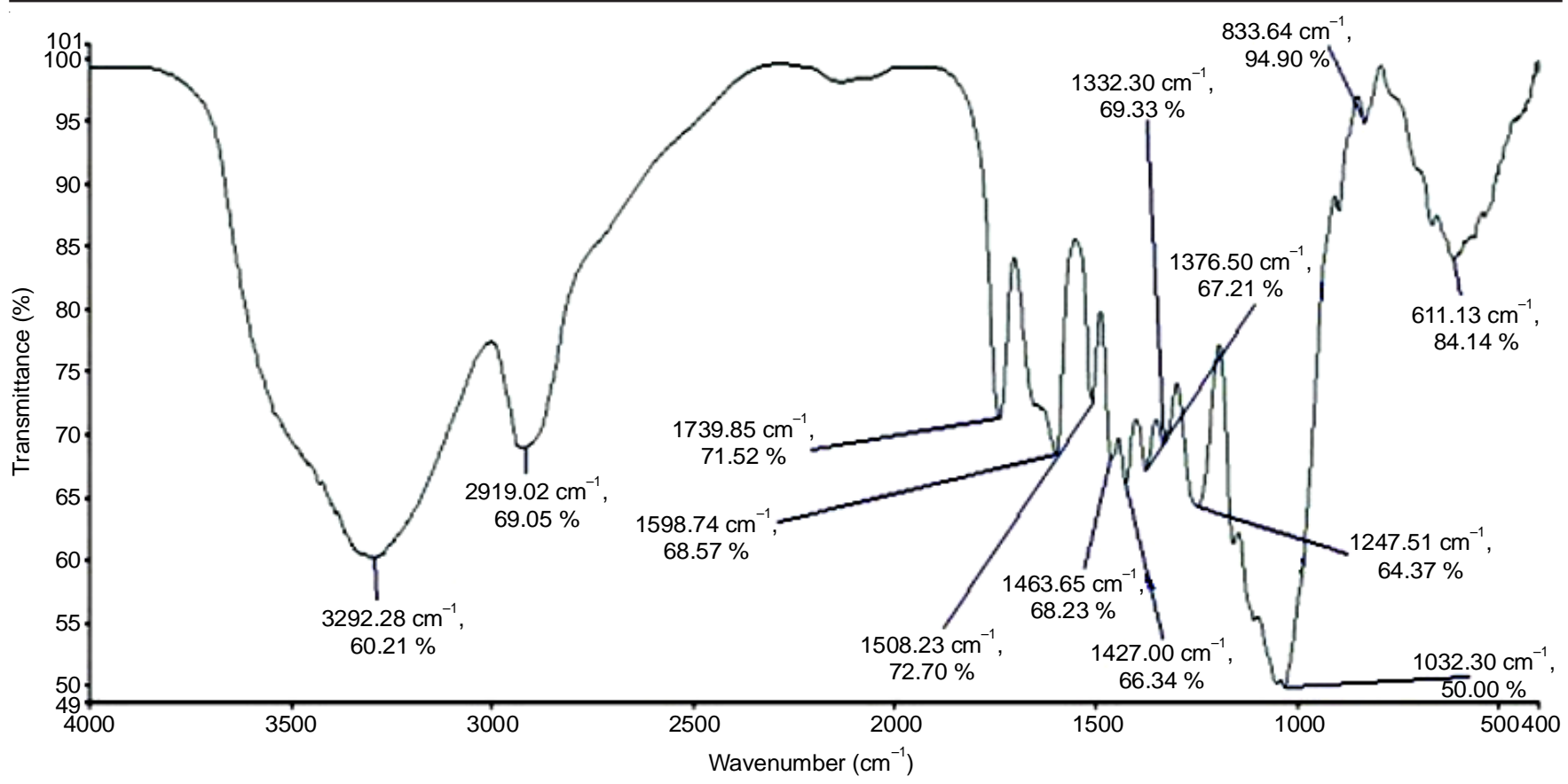

Fig. 1. FTIR spectrum of Limonia acidissima shells

$$
\ln \mathrm{K}_{\mathrm{c}}=\left(\frac{\Delta \mathrm{S}^{\circ}}{\mathrm{R}}-\frac{\Delta \mathrm{H}^{\circ}}{\mathrm{RT}}\right)
$$

The values $\left(\Delta \mathrm{H}^{\circ}\right)$ and $\left(\Delta \mathrm{S}^{\circ}\right)$ were calculating by using gradient and intercept of a graph called Van't Hoff equation, $\ln \mathrm{K}_{\mathrm{c}}$ versus 1/T [17].

\section{RESULTS AND DISCUSSION}

Characteristic of Limonia acidissima: The FTIR spectrum of Limonia acidissima shells (Fig. 1) was used to study the functional group. The band at $3600-3200 \mathrm{~cm}^{-1}$ is recognized due to $\mathrm{O}-\mathrm{H}$ and $\mathrm{N}-\mathrm{H}$ stretching groups. The absorption band at 1598 $\mathrm{cm}^{-1}$ is assigned to weak-stretching aromatic ring of $\mathrm{C}=\mathrm{C}$. The band at $1427 \mathrm{~cm}^{-1}$ are also observed, which are axial deformation and bending of $\mathrm{C}-\mathrm{H}$ of alkane dye structure. The XRD model was used to analyze the crystalline nature of Limonia acidissima shells (Fig. 2). The characteristic diffraction at around $18^{\circ}-25^{\circ}$

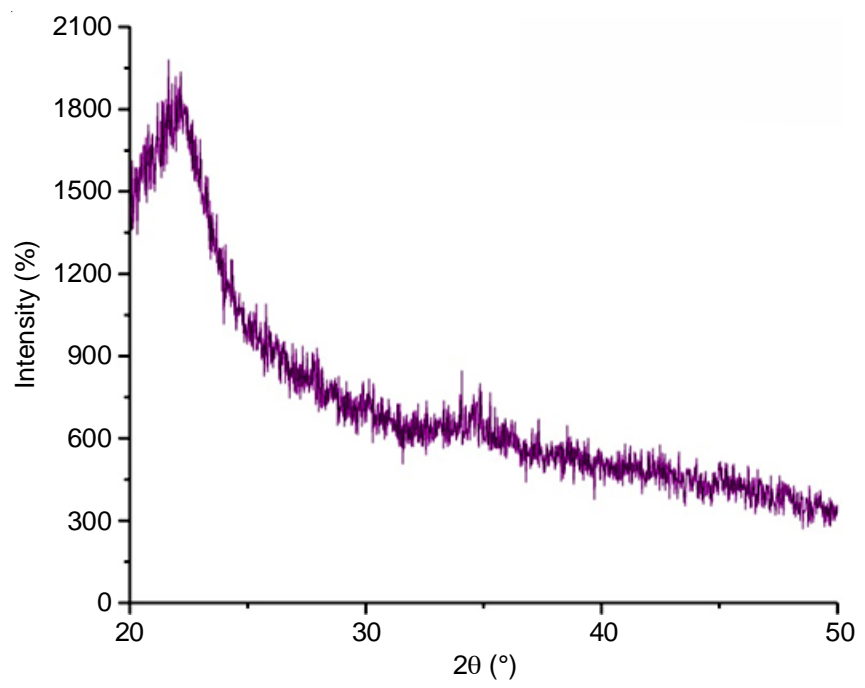

Fig. 2. X-ray diffraction graph of Limonia acidissima shells was detected in all diffractograms. The diffraction in spectrum, showed no obvious crystalline peak in the $10-70^{\circ}$ scanning range thus indicated the amorphous phase of L. acidissima shells.

Effect of initial concentration: The initial dye concentration and its effect on Congo red adsorption is understood by Fig. 3. To evaluate desired initial Congo red concentration, the initial concentration ranged from $50-100 \mathrm{mg} / \mathrm{L}$, maintaining the temperature, adsorbent dosage and time at $303 \mathrm{~K}, 0.05 \mathrm{~g}$ and $120 \mathrm{~min}$, respectively. The graph indicates that the percentage of elimination of Congo red dye decreases with increase Congo red dye concentrations; though the amount of adsorbed dye increases. Because increasing the concentration of dye, the surface area and their active sites of Limonia acidissima shells become saturated hence the removing percentage decreases [17].

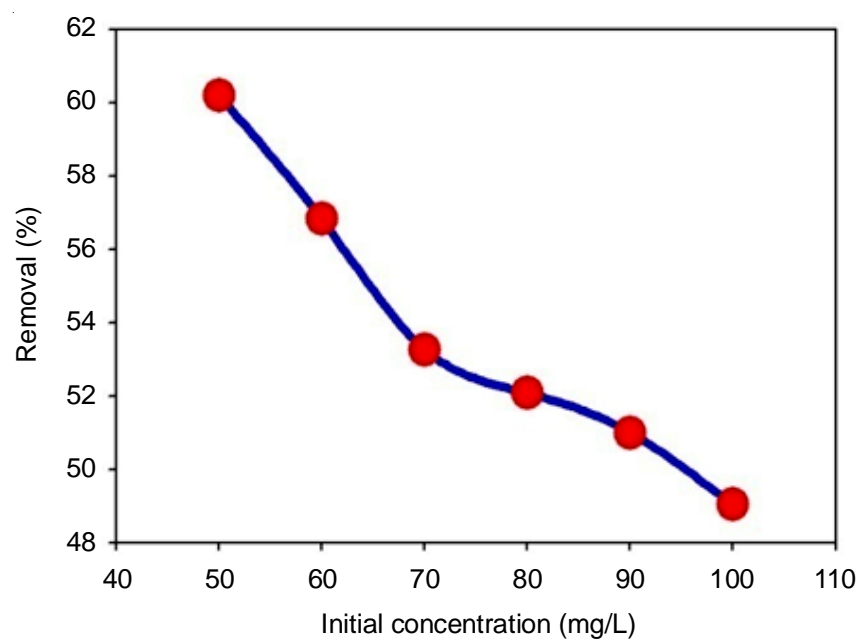

Fig. 3. Effect of different initial dye concentrations

Effect of contact time: Behaviour of Congo red dye on Limonia acidissima shells was studied to conclude an optimal contact time. It is observed (Fig. 4) that in a series of experiments i 


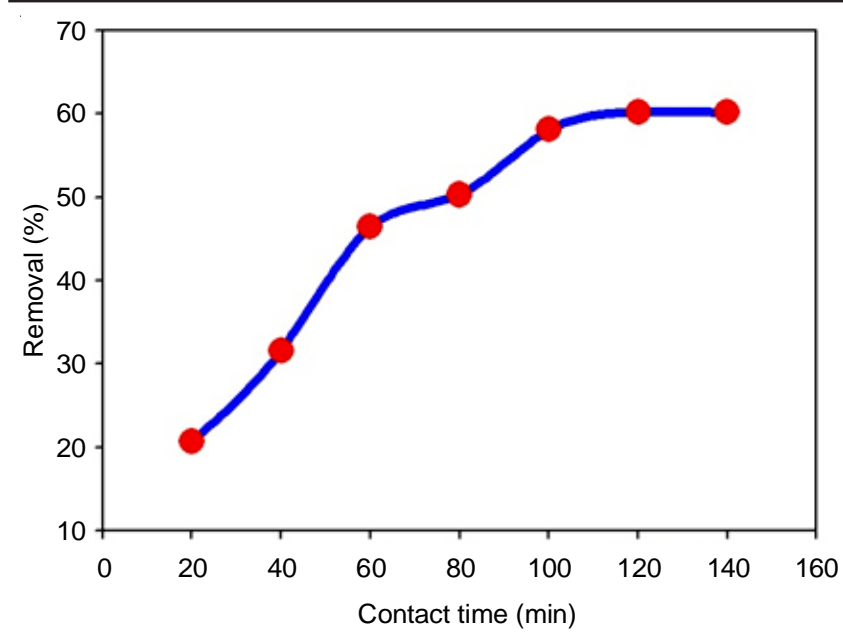

Fig. 4. Effect of different contact time

in which, initial concentration of Congo red dye, contact time, temperature and amount of adsorbent were $50 \mathrm{mg} / \mathrm{L}, 20-140$ min, $303 \mathrm{~K}$ and $0.05 \mathrm{~g}$, respectively. As can be seen in Fig. 4, Congo red dye adsorption is fast at the beginning and thereafter it almost constant as the equilibrium reached. This is due to fact that covering the active surface of Limonia acidissima shells by Congo red dye molecules which leads to saturation of Limonia acidissima shell surface [17].

Effect of Limonia acidissima shells dosage: Desired dosage of Limonia acidissima shells used for adsorption of Congo red dye is shown in Fig. 5. It is evident that the dye concentration $(50 \mathrm{mg} / \mathrm{L})$ were contacted with varing dosage of Limonia acidissima shells (0.5-50 mg) for $120 \mathrm{~min}$ at $303 \mathrm{~K}$. Due to a maximum number of active adsorbent sites availability, the removal percentage of Congo red elimination of dye is increased with the increase in adsorbing Limonia acidissima shells [18].

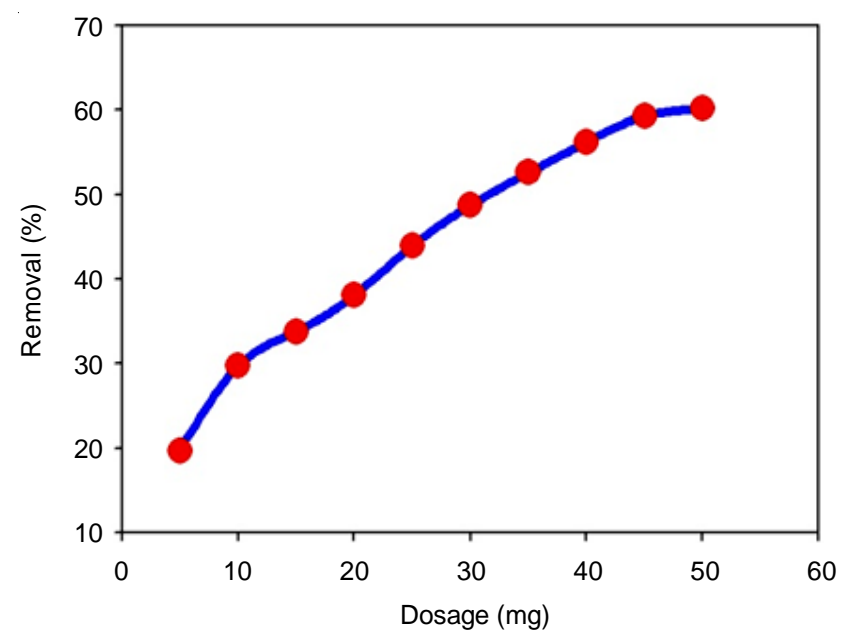

Fig. 5. Effect of various dosage of adsorbent
Adsorption isotherms: Experimental data collected at $303 \mathrm{~K}$ and a particular initial concentration of $50 \mathrm{mg} / \mathrm{L}$ were used on standard isotherm models applied in the aqueous solution viz., Langmuir, Freindlich, Temkin and Dubinin-Radushkevich (DR). The Langmuir adsorption isotherm is more suitable for describing adsorption equilibrium $\left(\mathrm{R}^{2}>0.9707\right)$. Therefore, it is assumed that Congo red dye covers $84.48 \mathrm{mg} / \mathrm{g}$. The $\mathrm{R}_{\mathrm{L}}$ value 0.76 calculated from eqn. 6 in the range 0 to 1 , favoured adsorption of Congo red dye on Limonia acidissima shells [13]. Freundlich isotherm is about to know the same system, is mostly explained the adsorption isotherms model at multiple sites.

The intensity of adsorption value is $n>1$ (1.896) shows a favourable and heterogeneous adsorption of congo red dye on Limonia acidissima shells. Temkin's isotherm explained the heat of adsorption of all molecules and the interaction of Congo red dye on Limonia acidissima shell surface. The amount of free energy (E) used to distinguish between physical $(<8 \mathrm{KJ} /$ $\mathrm{mol})$ and chemical adsorption $(8-16 \mathrm{~kJ} / \mathrm{mol})$ on the basis of ion- exchange. The free energy (E) of adsorption was found to be $0.117(\mathrm{~kJ} / \mathrm{mol})$, which favoured the physical adsorption. Table-1 summarizes values of the isotherm parameters. The best uptake isotherms are preferred based on the correlation coefficient of Langmuir and Freundlich adsorption isotherms.

Kinetic adsorption: The asset mechanism is determined by a kinetic model that provides useful data to increase adsorption efficiency and broaden process possibilities. Rate constant was calculated by using the pseudo first-order rate model, pseudo second-order rate model and the intra-particle-diffusion model. The data obtained by Congo red surprise at Limonia acidissimais shell based on a primary liability dynamics model in which adsorption dynamics does not coincide well with the model of first principle as shown in Fig. 6. These results explained that the pseudo-second-order (0.9735) is higher than pseudofirst-order model (> 0.9141) for Limonia acidissimais shell. The results obtained through Fig. 7 indicated that the adsorption data is well represented by pseudo-second order rate model. Its degree can be limited to the adsorption rate in the specific surface area, which is attributed due to the lack of internal circulation. Of course, hypothetical behavior may include valence by separating electrons between anions and cations. In an intra-particle diffusion model for solid and liquid phase adsorption processes, the behaviour of dissolved substances is generally studied by external mass transfer or dispersion within the particles. The particles distribution model by intraparticle diffusion model [18]. To see the mechanism associated with the sorption is shown in Fig. 8. Table-2 provides the parameters and coefficients of pseudo first-order rate model and pseudo second-order rate model and intraparticle diffusion model.

Effect of temperature and thermodynamics adsorption studies: Experiments were conducted in batches conditions

\begin{tabular}{|c|c|c|c|c|c|c|c|}
\hline \multicolumn{8}{|c|}{$\begin{array}{c}\text { TABLE-1 } \\
\text { DIFFERENT ADSORPTION ISOTHERM MODEL PARAMETERS OF CONGRO RED DYE }\end{array}$} \\
\hline \multicolumn{4}{|c|}{ Langmuir isotherm } & \multicolumn{4}{|c|}{ Freundlich isotherm } \\
\hline $\mathrm{Q}_{\mathrm{o}}\left(\mathrm{mg} \mathrm{g}^{-1}\right)$ & $\mathrm{K}_{\mathrm{L}}\left(\mathrm{L} \mathrm{mg}^{-1}\right)$ & & $\mathrm{R}^{2}$ & $1 / \mathrm{n}$ & & $\mathrm{K}_{\mathrm{F}}\left(\mathrm{mg} \mathrm{g}^{-1}\right)$ & $\mathrm{R}^{2}$ \\
\hline 84.78 & 0.0260 & 0.7680 & 0.97077 & 0.5271 & 1.8968 & 6.1308 & 0.9600 \\
\hline \multicolumn{4}{|c|}{ Temkin Isotherm } & \multicolumn{4}{|c|}{ Dubinin Radushkevich Isotherm } \\
\hline $\mathrm{A}_{\mathrm{T}}\left(\mathrm{L} \mathrm{mg}^{-1}\right)$ & $\mathrm{b}_{\mathrm{T}}$ & $\mathrm{B}$ & $\mathrm{R}^{2}$ & $\mathrm{q}_{\mathrm{s}}\left(\mathrm{mg} \mathrm{g}^{-1}\right)$ & $\mathrm{K}_{\mathrm{ad}}\left(\mathrm{mol}^{2} \mathrm{KJ}^{-2}\right)$ & $\mathrm{E}\left(\mathrm{KJ} \mathrm{mol}^{-1}\right)$ & $\mathrm{R}^{2}$ \\
\hline 4.2715 & 123.533 & 20.392 & 0.9703 & 10.62 & $3.6091 \times 10^{-5}$ & 0.117 & 0.8928 \\
\hline
\end{tabular}




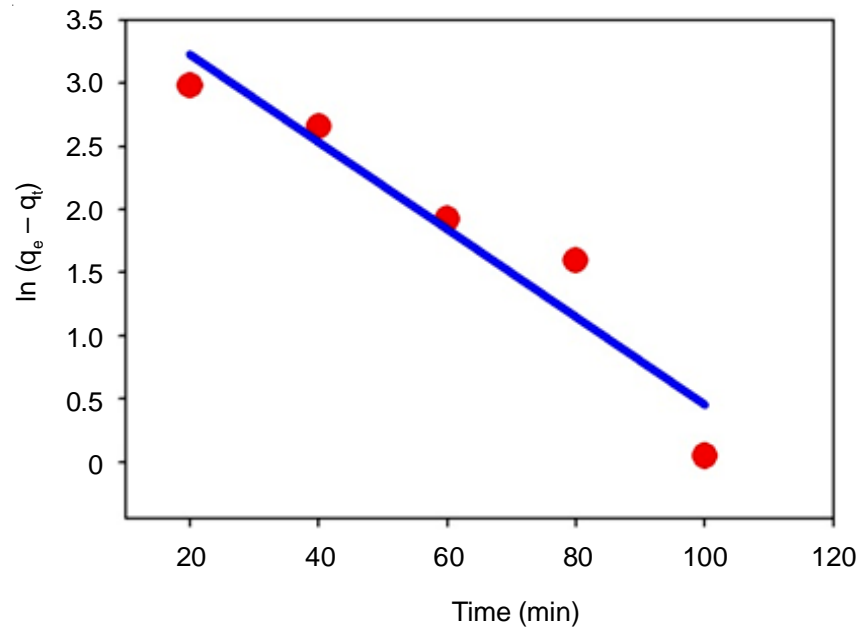

Fig. 6. Pseudo first-order plot for adsorption

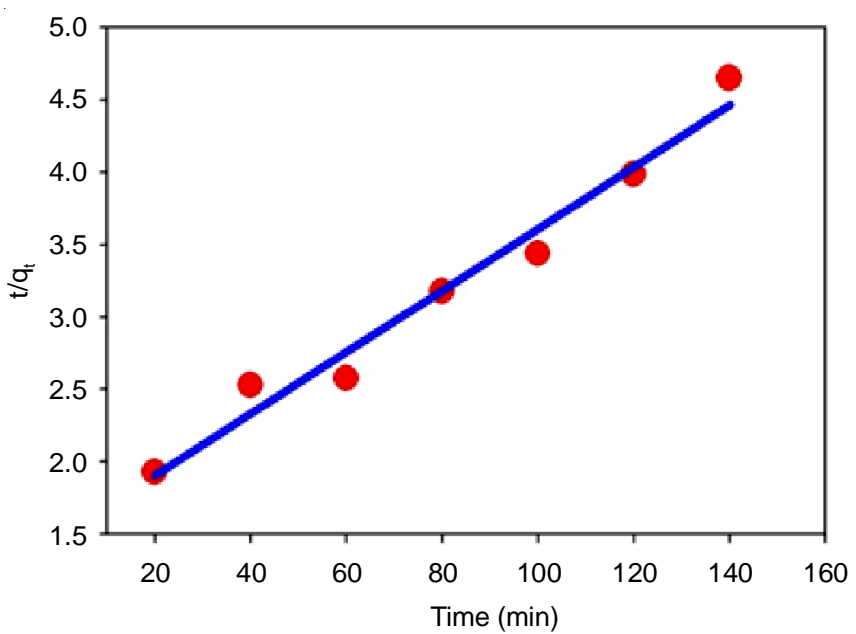

Fig. 7. Pseudo second-order plot for adsorption

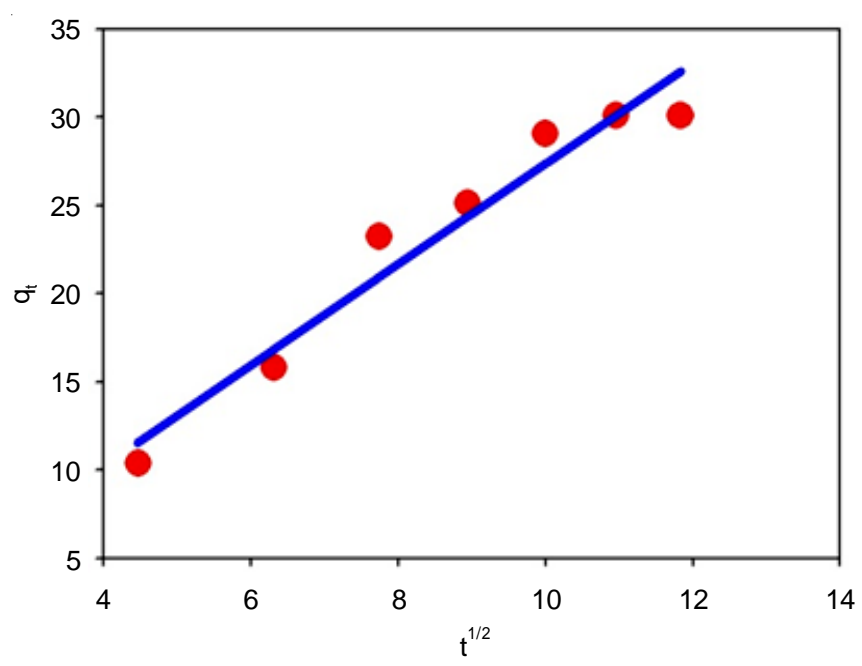

Fig. 8. Intra-particle-diffusion plot for adsorption

at particular temperatures viz., 303, 313, 323 and $333 \mathrm{~K}$. The adsorption of Congo red increased from 60.2 to $70.9 \mathrm{mg} / \mathrm{g}$ with increase in temperature. This indicates that this is an endothermic process. The rise in temperature leads to increase in active sites of adsorbent [19]. The different thermodynamic properties were determined such as $\Delta \mathrm{G}^{\circ}, \Delta \mathrm{S}^{\circ}$ and $\Delta \mathrm{H}^{\circ}$. The van't Hoff equation shows a linear form of $\log \left(\mathrm{K}_{\mathrm{c}}\right) / \mathrm{T}$
TABLE-2

SUMMARY OF PARAMETERS FOR VARIOUS KINETIC MODELS AND THERMODYNAMICS PROPERTIES

\begin{tabular}{|c|c|c|c|}
\hline Kinetic model & & Value & $\mathrm{R}^{2}$ \\
\hline Pseudo first-order & $\begin{array}{l}\mathrm{Q}_{\mathrm{e}}\left(\mathrm{mg} \mathrm{g} \mathrm{g}^{-1}\right) \\
\mathrm{K}_{1}(\mathrm{~min})^{-1}\end{array}$ & $\begin{array}{c}10.66 \\
0.0346 \\
\end{array}$ & 0.9141 \\
\hline $\begin{array}{l}\text { Pseudo second- } \\
\text { order }\end{array}$ & $\begin{array}{l}\mathrm{q}_{\mathrm{e}}\left(\mathrm{mgg}^{-1}\right) \\
\mathrm{K}_{2}\left(\mathrm{~g} \mathrm{mg}^{-1} \min ^{-1}\right)\end{array}$ & $\begin{array}{l}0.6745 \\
0.0096 \\
\end{array}$ & 0.9735 \\
\hline $\begin{array}{l}\text { Intra-particle } \\
\text { diffusion }\end{array}$ & $\begin{array}{l}\mathrm{K}_{\mathrm{id}}\left(\mathrm{g} \mathrm{mg}^{-1} \min ^{-0.5}\right) \\
\mathrm{C}\left(\mathrm{mg} \mathrm{g}^{-1}\right)\end{array}$ & $\begin{array}{l}2.8583 \\
1.1211 \\
\end{array}$ & 0.9496 \\
\hline \multirow{3}{*}{$\begin{array}{l}\text { Thermodynamic } \\
\text { Properties }\end{array}$} & $\begin{array}{l}\Delta \mathrm{H}^{\circ}\left(\mathrm{J} \mathrm{mol}^{-1}\right) \\
\Delta \mathrm{S}^{\circ}\left(\mathrm{J} \mathrm{mol}^{-1} \mathrm{~K}^{-1}\right)\end{array}$ & $\begin{array}{c}6.637 \\
14.208 \\
\end{array}$ & 0.9980 \\
\hline & $-\Delta \mathrm{G}^{\circ} \times 10^{2}\left(\mathrm{~kJ} \mathrm{~mol}^{-1}\right)$ & & \\
\hline & \begin{tabular}{|l|}
$303 \mathrm{~K}$ \\
$313 \mathrm{~K}$ \\
$323 \mathrm{~K}$ \\
$333 \mathrm{~K}$ \\
\end{tabular} & $\begin{array}{l}10.93 \\
11.05 \\
11.24 \\
11.37 \\
\end{array}$ & 0.9980 \\
\hline
\end{tabular}

(Fig. 9), which was further used for calculating the thermodynamic parameters with eqn. 12 . The $\Delta \mathrm{H}^{\circ}$ and $\Delta \mathrm{S}^{\circ}$ positive values indicate endothermic environment and randomness of Congo red-Limonia acidissimais shell solution of the adsorbents internal structure. The negative value of $\Delta \mathrm{G}^{\circ}$ suggested a favourable adsorption at various temperatures [20].

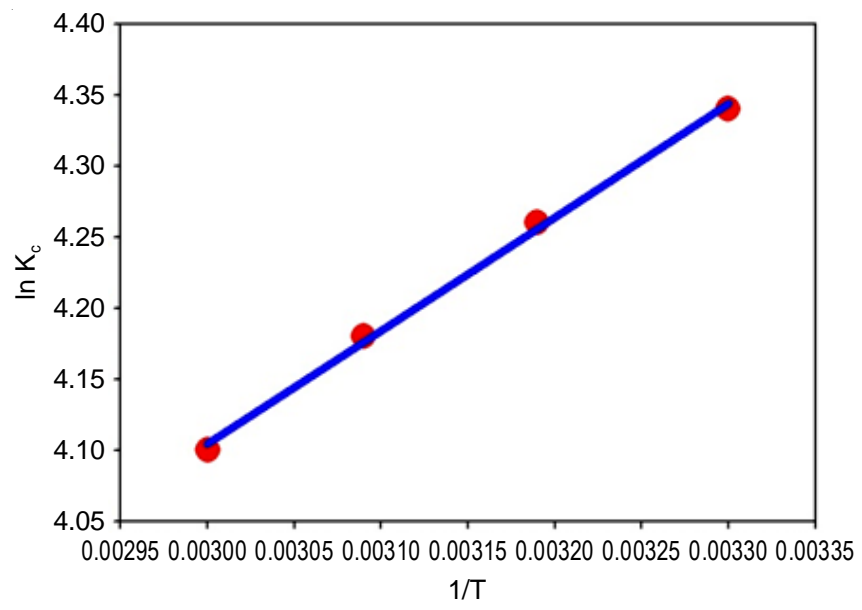

Fig. 9. van't Hoff plot for Congo red adsorption

Comparison of adsorption capacity of congo red dye with various adsorbents: Various materials as adsorbents have been investigated for the elimination of Congo red dye. Table-3 summaries the maximum adsorption capacity from Langmuir isotherm model by numerous adsorbents. So, it is clear from Table-3 that the Limonia acidissima shell as waste material exhibits the higher adsorption capacity in case of Congo red dye adsorption.

\section{Conclusion}

The potential of Limonia acidissima shells as adsorbent in the elimination of Congo red dye in batch mode is investigated. The several parameters likes dosage, temperatures, initial concentration and contact time were evaluated in order to check the efficiency of Limonia acidissima shell as adsorbent towards Congo red dye. Highest adsorbent capacity $(60.2 \mathrm{mg} / \mathrm{g})$ of $L$. acidissima shells on congo red dye were achieved at $\mathrm{pH} 4$ within $120 \mathrm{~min}$. Various adsorption isotherm models viz. Langmuir, Freundlich, Temkin and Dubinin-Radushkevitch isotherms were studied. The maximum amount adsorbed $84.48 \mathrm{mg} / \mathrm{g}$ by 


\begin{tabular}{lcc}
\hline \multicolumn{3}{c}{ TABLE-3 } \\
\multicolumn{1}{c}{ SUMMARIES THE MAXIMUM ADSORPTION } \\
CAPACITY WITH NUMEROUS ADSORBENT \\
\hline \multicolumn{1}{c}{ Adsorbents } & $\begin{array}{c}\text { Maximum } \\
\text { adsorption } \\
\text { capacity } \\
\text { (mg/g) }\end{array}$ & Ref. \\
\hline & 5.18 & {$[21]$} \\
\hline Cashew nut shell & 5.44 & {$[22]$} \\
Clay materials & 10.00 & {$[23]$} \\
Pomegranate based activated carbon & 11.89 & {$[24]$} \\
Bagasse fly ash & 14.49 & {$[25]$} \\
E. crassipes & 19.20 & {$[23]$} \\
Myrtus communis based activated carbon & 32.25 & {$[26]$} \\
Tea waste & 38.79 & {$[27]$} \\
Cattail root & 43.47 & {$[26]$} \\
Tea waste (vibrating mill treated) & 54.52 & {$[28]$} \\
Chitosan nanocomposite & 67.84 & {$[29]$} \\
Neem leaves & 84.78 & Present \\
Limonia acidissima shell & & study \\
\hline
\end{tabular}

Langmuir isotherm was achieved. All of them, Freundlich isotherm model is best fitted. In addition, the kinetic of the overall adsorption were investigated by pseudo first-order and pseudo second-order. The pseudo second-order model favoured the adsorption of Congo red dye on Limonia acidissima shells. The fast adsorption of Congo red dye on Limonia acidissima shells showed by intra-particle diffusion. The thermodynamics parameters indicate an endothermic process for adsorption process. The positive value of $\Delta \mathrm{S}^{\circ}$ confirmed greater stability of adsorption process of Congo red on Limonia acidissima shells.

\section{CONFLICT OF INTEREST}

The authors declare that there is no conflict of interests regarding the publication of this article.

\section{REFERENCES}

1. M.S. Chiou, P.Y. Ho and H.Y. Li, Dyes Pigments, 60, 69 (2004); https://doi.org/10.1016/S0143-7208(03)00140-2.

2. $\quad$ S. Sen and G.N. Demirer, J. Environ. Eng., 129, 595 (2003); https://doi.org/10.1061/(ASCE)0733-9372(2003)129:7(595).

3. S. Seshadri, P.L. Bishop and A.M. Agha, Waste Manag., 14, 127 (1994); https://doi.org/10.1016/0956-053X(94)90005-1.

4. C. Prasse, D. Stalter, U. Schulte-Oehlmann, J. Oehlmann and T.A. Ternes, Water Res., 87, 237 (2015); https://doi.org/10.1016/j.watres.2015.09.023.

5. V.K. Gupta, P.J.M. Carrott, M.M.L. Ribeiro Carrott and Suhas, Crit. Rev. Environ. Sci. Technol., 39, 783 (2009); https://doi.org/10.1080/10643380801977610.

6. V.J.P. Poots, G. McKay and J.J. Healy, Water Res., 10, 1067 (1976); https://doi.org/10.1016/0043-1354(76)90037-3.
7. G. McKay, M. El Geundi and M.M. Nassar, Water Res., 21, 1513 (1987); https://doi.org/10.1016/0043-1354(87)90135-7.

8. G. McKay, G. Ramprasad and P. Mowli, Water Res., 21, 375 (1987); https://doi.org/10.1016/0043-1354(87)90218-1.

9. S. Jain and R.V. Jayaram, Desalination, 250, 921 (2010); https://doi.org/10.1016/j.desal.2009.04.005.

10. N.A. Fathy, S.S. Sayed Ahmed and R.M.M. Abo El-Enin, Environ. Res. Eng. Manag., 59, 10 (2012); https://doi.org/10.5755/j01.erem.59.1.961.

11. T.K. Sen, S. Afroze and H.M. Ang, Water Air Soil Pollut., 218, 499 (2011); https://doi.org/10.1007/s11270-010-0663-y.

12. S. Ho and G. McKay, Process Biochem., 34, 451 (1999); https://doi.org/10.1016/S0032-9592(98)00112-5.

13. B. Meroufel, O. Benali, M. Benyahia, Y. Benmoussa and M.A. Zenasni, J. Mater. Environ. Sci., 4, 482 (2013).

14. O. Uner, U. Geçgel, H. Kolancilar and Y. Bayrak, Chem. Eng. Commun., 204, 772 (2017): https://doi.org/10.1080/00986445.2017.1319361.

15. H.M.H. Gad and A.A. El-Sayed, J. Hazard. Mater, 168, 1070 (2009); https://doi.org/10.1016/j.jhazmat.2009.02.155.

16. R. Laus, T.G. Costa, B. Szpoganicz and V.T. Fávere, J. Hazard. Mater, 183, 233 (2010); https://doi.org/10.1016/j.jhazmat.2010.07.016.

17. M. Aliabadi, I. Khazaei, H. Fakhraee and M.T.H. Mousavian, Int. J. Environ. Sci. Technol., 9, 319 (2012); https://doi.org/10.1007/s13762-012-0045-7.

18. M. Delavar, A.A. Ghoreyshi, M. Jahanshahi and N. Nabian, J. Exp. Nanosci., 9, 310 (2014); https://doi.org/10.1080/17458080.2012.661470.

19. S. Banerjee and M.C. Chattopadhyaya, Arab. J. Chem., 10, 1629 (2017); https://doi.org/10.1016/j.arabjc.2013.06.005.

20. A.M. Aljeboree, A.N. Alshirifi and A.F. Alkaim, Arab. J. Chem., 10, 3381 (2017); https://doi.org/10.1016/j.arabjc.2014.01.020.

21. P. Senthil Kumar, S. Ramalingam, C. Senthamarai, M. Niranjanaa, P. Vijayalakshmi and S. Sivanesan, Desalination, 261, 52 (2010); https://doi.org/10.1016/j.desal.2010.05.032.

22. V. Vimonses, S. Lei, B. Jin, C.W.K. Chow and C. Saint, Chem. Eng. J., 148, 354 (2009); https://doi.org/10.1016/j.cej.2008.09.009.

23. M. Ghaedi, H. Tavallali, M. Sharifi, S.N. Kokhdan and A. Asghari, Spectrochim. Acta A Mol. Biomol. Spectrosc., 86, 107 (2012); https://doi.org/10.1016/j.saa.2011.10.012.

24. I.D. Mall, V.C. Srivastava, N.K. Agarwal and I.M. Mishra, Chemosphere, 61, 492 (2005); https://doi.org/10.1016/j.chemosphere.2005.03.065.

25. T.K. Roy and N.K. Mondal, Appl. Water Sci., 7, 1841 (2017); https://doi.org/10.1007/s13201-015-0358-z.

26. M. Foroughi-Dahr, H. Abolghasemi, M. Esmaili, A. Shojamoradi and H. Fatoorehchi, Chem. Eng. Commun., 202, 181 (2015); https://doi.org/10.1080/00986445.2013.836633.

27. Z. Hu, H. Chen, F. Ji and S. Yuan, J. Hazard. Mater, 173, 292 (2010); https://doi.org/10.1016/j.jhazmat.2009.08.082.

28. L. Wang and A. Wang, J. Hazard. Mater., 147, 979 (2007); https://doi.org/10.1016/j.jhazmat.2007.01.145.

29. S.P. Raghuvanshi, R. Singh and C.P. Kaushik, Asian J. Chem., 20, 4994 (2008). 